\title{
The Association between Executive Turnover, Family Business and Firm Performance: Evidence in Taiwan
}

\author{
Ling-Ling Chang \\ Department of Accounting, Ming-Chuan University, Taipei, Taiwan
}

Tel: 886-2-28824564 Email: 1lchang@mail.mcu.edu.tw

Fujen Daniel Hsiao (Corresponding author)

Department of Accounting, University of Minnesota Duluth

1318 Kirby Drive, LSBE 360G, Duluth, MN 55812, USA

Tel: 1-218-7267454 Email: fhsiao@d.umn.edu

Yan $\mathrm{Hu}$

Department of Finance, University of Minnesota Duluth, USA

Tel: 1-218-7267083 Email: yhu@d.umn.edu

Received: September 16, 2012

Accepted: October 23, 2012

Online Published: October 25, 2012

doi:10.5430/afr.v1n2p148

URL: http://dx.doi.org/10.5430/afr.v1n2p148

\begin{abstract}
This study examines the relationship between the turnover of high-level executives and firm performance in Taiwan. Prior studies of executive turnover focus solely on changes to a firms' Chief Executive Officer (CEO), Board of Director (BOD) Chair, or Chief Financial Officer (CFO). This study is the first to include the role of Chief Accounting Officers (CAO) in our analysis and investigation of executive turnover and its effect on firm performance. Chief Accounting Officers of Taiwanese firms, are required to certify financial statements and provide assurance of financial reporting, a special requirement unique to Taiwan. Additionally, our study weighs factors of family-owned business and the tenure of executives against their effect on firm performance. Our results suggest a negative association between executive turnover and accounting performance; market performance of price to book ratio (PB ratio), however, is not significantly related to various types of turnovers except the turnover of the CEO. Moreover, our findings demonstrate that longer management tenure does not lead to improvement in firm performance and may result in negative market valuations.
\end{abstract}

Keywords: Executive turnover, Chief accounting officer, Accounting performance, Market performance

\section{Introduction}

Critical to the success of business operations is leadership provided by a strong executive team. It is common for a firm's board of directors (BOD) to change executive-level managers due to the failure of managers to achieve specified business targets. For example, Yahoo! has experienced five changes of its Chief Executive Officer (CEO) and two changes of BOD chair since 2007, despite any certainty that these incoming executives can lead the firm to success or directly affect firm performance. When business fundamentals and firm performance do not improve in a short period of time, the BOD may once again demand a change in the firm's executive ranks.

Passage of the Sarbanes-Oxley Act of 2002 (SOX) intended to protect investors by emphasizing the responsibility of the corporate board, especially the responsibility of the audit committee, and high-level management. This regulation required CEOs and CFOs to certify financial statements and to verify financial reporting accuracy; strict penalties came to those who violated these provisions. Following in the spirit of SOX, the Taiwan government in 2005 demanded that Chief Accounting Officers (CAOs) of public firms certify financial reporting in addition to the certification requirement of the firms' CEOs, CFOs, and Board Chairs. Due to double legal liabilities of the provisions for $\mathrm{CFO}$ and $\mathrm{CAO}$ under the new law, many CFOs of public companies split their duties into two separate 
positions and "created" (or "promoted") an accountant-in-charge to become the CAO, thus minimizing CFO responsibilities and the double legal liability of the CFO position. Thus, our study includes the important factor of $\mathrm{CAO}$ turnover into its empirical examination of firm performance.

When a firm's financial results are not as expected, executives may, under pressure to retain their positions, engage in financial reporting practices that manipulate earnings. Such actions place executives at greater risk of legal liability and may cause them to voluntarily leave s position for self-protection. Therefore, it is likely that there is an association between a firm's executive turnover and its recent accounting and market performance. Prior studies regarding executive turnover and firm performance focus only on CEO or BOD Chair turnovers; there is no research, however that includes the role of CAO in the empirical study. From the unique setting of the CAO requirement in Taiwan, a further examination of firm performance will provide insights into this line of research.

Family owned businesses (FOB) are the backbone of many economies around the world, and family businesses represent a significant number of Taiwanese listed firms. It is important to distinguish family and non-family firms when examining firm performance. There are mixed empirical results regarding firm performance of family businesses shown in prior studies (Claessen et al., 2002; Khanna, 2000a; Anderson and Reeb, 2003). Since family businesses are generally considered lax in corporate governance compared to non-family business firms (Non-FOB), especially in the detail of financial disclosure and information transparency, our empirical examination will provide evidence regarding this difference on their firm performance.

Prior literature indicates that lengthy tenure of firm's executives may impact executives' business decisions and reduce BOD's monitoring of the firm, which may result in less incentive for executives to seek enhancement of firm performance (Hermalin and Weisbach, 1998). Gong (2011) argues that CEO compensation and increases in shareholder value added aggregate naturally over CEO tenure, and CEO pay efficiency is higher if median pay-for-performance sensitivity during CEO tenure is higher. Thus, our research is further interested in examining the association of executives' tenure with their firm performance.

Our empirical findings indicate that (1) the firm's executive turnover is negatively associated with accounting performance, regardless of various levels of executive change. Results, however, do not support that the firm's executive turnover may associate with firm's market performance; the only exception was a positive relation related to CEO turnover. (2) The accounting performance of family-owned businesses underperforms compared to non-family businesses; however, the response of firms' market performance is marginally weaker for family businesses versus their counterpart of non-family firms. (3) The longer tenures of CEO and BOD chair reversely associated with their firm's market performance, which implies that the market does not value lengthy executive tenure.

The contributions of this study are numerous. This is the first empirical study to consider CAO turnover and its influence on firm performance due to the newly created legal liability requiring certification of financial statements, unique to Taiwan. Our study also incorporates the firm's market performance, a differentiation from accounting performance, to measure with the factors from family-owned businesses and firms' executive tenure. The remainder of this paper is organized as follows: Section 2 presents recent literature for review and develops our hypotheses. It is followed by an outline of research methods in Section 3; empirical results and analysis in Section 4; and concludes with a brief summary in Section 5 .

\section{Literature Reviews}

\subsection{Theories on management turnover}

Prior literature suggests that executive turnover is commonly attributed to (1) common-sense hypothesis, (2) vicious cycle hypothesis, and (3) ritual scapegoat hypothesis. In common-sense hypothesis, BOD of the firm selects the best qualified managers to lead the company, replacing under-performing managers. The change results in a positive impact and an improvement of firm performance (Murphy and Zimmerman, 1993). The view point from vicious cycle hypothesis is the opposite: it cites a reverse and negative impact on performance when inefficient managers are replaced within the firm. Grusky (1963) argues that when a firm takes considerable time to adjust to new leadership due to management turnover, tension and internal conflict cause even lower firm performance. Therefore, a company with turnover will undergo another management change due to low performance, and the vicious cycle continues when its stock price drops yet again (Beatty and Zajac, 1987; Bendeck and Waller, 1999; Warner et al. 1988; Lubatkin et al., 1989). Ritual scapegoat hypothesis, however, suggests that firm performance is not relevant to executive turnover. Gamson and Scotch (1964) suggest that only a firm with a structural problem results in poor performance. To blame performance on the management team, without taking other factors into consideration, is 
merely a scapegoat of the entire situation. Thus, share prices are not believed to change simply due to the turnover in firm management (Eitzen and Yetman, 1972; McGuire et al., 1998).

However, mixed empirical results appear to be driven by the intent of executive turnover. Mahajan and Lummer (1993) document a positive market reaction when replacement of high-level managers is due to poor performance but share price drops if managers leave on their own volition or leap to better positions. Furthermore, studies from Friedman and Singh (1989) and Bendeck and Waller (1999) report positive market reaction to turnover when the firm performs poorly prior to the change of management due to the expectation of improvement associated with new management. However, stock prices could drop due to investors' concerns when executive turnover occurs in well-performing companies.

Wang (2008) states that stock market reaction supports "common sense hypothesis" for executive turnover when executive turnover occurs in a bull market; market reaction tends to follow "vicious cycles hypothesis" when executive turnover occurs in a bear market. However, if the market is between bear and bull cycles, market reaction supports "ritual scapegoat hypothesis." Additionally, Hsu (2008) examines firm performance related to CFO changes in Taiwan and finds that CFO turnover often occurs if a firm reports poor accounting performance and poor market performance. However, when financial results of the firm outperform its counterparts in the industry, and market performance still decreases, the firm is more likely to rotate the CFO, and shake up organizational structure.

This occurs regardless of the industry or how close a CFO lies to retirement age. Tsai and Wang (2009) find abnormal returns are no different before a firm announces CFO turnover, but more pronounced after the announcement is made. Thus, this research concludes that CFO turnover may positively influence an organization and result in better firm performance.

Based on the above discussion, we find the performance of a firm can be measured by either its accounting performance or market performance. Hence we employ the firm's return on assets (ROA) as a measure of accounting performance, whereas the firm's market performance is proxy by its price to book ratio (PB ratio). In addition, we are also able to break down the turnover of high-level executives such as the CEO, CFO, CAO, and BOD Chair, by empirically examining their relationship with firm performance.

Thus, our first set of hypotheses follows (stated in null form):

H1a: Firms' high level executive turnover is not associated with the firms' recent accounting performance.

H1b: Firms' high level executive turnover is not associated with the firms' recent market performance.

\subsection{Family business and firm performance}

Many emerging markets consist of a great number of firms listed as family-controlled businesses (Chen, 2002; Claessens et al., 2000; La Porta et al., 1999). Prior research shows that family firms in Southeast Asia perform better and gain greater valuation than their counterparts of non-family businesses (McConaughy et al., 1998; Khanna and Palepu, 2000a, 200b; Anderson and Reeb, 2003; Maury, 2006; Saito, 2008). In contrast, other studies point out that firms that are family controlled are more likely to be valued less on the firm valuation and decrease their shareholder wealth (Morck et al., 2000; Schulze et al., 2002; Claessens, et al., 2002; Miller et al., 2007). Thus, there remain mixed empirical results for firm performance of family businesses. According to the Taiwan Economics Journal Database (TEJ), the majority (roughly 69\%) of Taiwanese listed firms is classified as family-controlled business; therefore it is important to distinguish family and non-family firms when examining firm performance. Claessen et al. (2002) examine eight Southeast Asian markets and determine that family businesses underperformed non-family businesses. Additionally, Miller et al. (2007) report similar underperformance by family businesses in the U.S.

When looking at governance mechanisms, family firms are generally considered less regulated than non-family businesses. Prior studies indicate these firms would be valued higher if they were to be more transparent when disclosing financial information and if they were to exercise stronger corporate governance, two characteristics family-owned businesses have generally be known to lack. This finding is consistent with recent trends whereby both investors and regulators (such as the SEC), demand greater disclosure and transparency of firm information which reduces information asymmetry; factors that may induce the market to respond favorably (Merton, 1987; Claessens et al., 2002; La Porta et al., 2002). Additionally, Mitton (2002) provides evidence from the examination of firms in Southeast Asian countries, reports improved firm performance for the firms that disclose large amounts of information with greater transparency.

Thus, our second set of hypotheses follows (stated in null form): 
H2a: Whether firms are considered a family-owned or non-family owned business is not associated with firms' recent accounting performance.

H2b: Whether firms are considered a family-owned or non-family owned business is not associated with firms' recent market performance.

\subsection{Management tenure and firm performance}

Hermalin and Weisbach (1998) find that CEO's negotiation power increases with longer tenure in the firm due to CEO influence on board member selection, which in turn results in less monitoring of CEO behavior by the board. This also suggests that a CEO with longer tenure will have lower probability of termination, thus he (she) has less incentive to proactively engage in improving activities to improve firm performance. Miller and Shamsie (2001) find that firm performance increases for the first eight to ten years of CEO's tenure and then begins to decrease. Additionally, Lansberg (1999) and Ward (2004) state that CEOs of FOB stay at the job three to five times longer than those of Non-FOB, which may also imply that firm performance may be impacted by the length of tenure. Gong (2011) argues that CEO compensation and shareholder value aggregate naturally over CEO tenure, and CEO pay efficiency is higher if median pay-for-performance sensitivity during CEO tenure is higher. Therefore, we argue that longer CEO tenure in a firm will result in a more experienced and more powerful CEO for that firm. The CEO, therefore, is able to contribute greatly to the company in which he (she) receives much higher pay. However, an unsolved question remains about how the market will respond to the effect of longer CEO tenure to the firm's market performance. At the same time, we also examine whether the same effect applies to firm performance relative to BOD chair tenure.

Thus, our third set of hypotheses follows (stated in null form):

H3a: The tenure of CEO and BOD Chair is not associated with firms' recent accounting performance.

H3b: The tenure of CEO and BOD Chair is not associated with firms' recent market performance.

\subsection{Other governance factors}

Prior studies draw no consensus on the effect of duality of CEO and BOD Chair to firm performance. Studies from Daily and Dalton (1993) and Dahya et al. (1996) argue that there is negative impact on performance due to monitoring from the board, which is weakened. Yet, another viewpoint reflecting a positive influence on firm performance is supported by Boyd (1994). However, numerous empirical findings indicate that firms with CEO and chair duality have no significant impact on firm performance (Baliga et al., 1996; Dalton et al., 1998; Vafeas and Theodorou, 1998; Weir and Laing, 1999). Family owned businesses tend to employ a number of family members to sit on the board (Ali et al., 2007); this may deprive the wealth gained from other minority shareholders (Stearns and Mizruchi, 1993). La Porta et al. (1999) find that many firms are governed by ultimate controlling shareholders, who have considerable power over the firm's excess cash flow rights, primarily through the use of pyramids and the participation of management. Therefore, firm value is lower with higher deviation of controlling ownership interests. Furthermore, Yeh et al. (2001) find a reverse association between the number of controlling shareholders on the board and firm performance, suggesting that shareholders' interest is consistent with the firm's interests when cash flow rights are greater for controlling shareholders. We argue that firms may experience weaker corporate governance when there is higher deviation of controlling shareholders' cash flow rights from controlled equity ownership. This results in less monitoring by the board and may lead to manipulation of firm performance.

\section{Methodology}

We obtained data from the Taiwan Economic Journal (TEJ) database regarding executive turnovers and company financials for all companies listed between years 2006-2009. Our study initially collected 2,487 samples but eliminated 264 firm-years due to missing data. The remaining 2,223 firm-year observations excluded financial firms due to the strict regulatory requirements of financial industry executives that differ from executives in other industries. The measures regarding family owned businesses and Chair and CEO tenure in our study are all defined and followed by TEJ. Executive tenure is measured by years of service in the same position. The family firm is more restrictively defined and identified as those where the largest controlling shareholder is a family group and at least two family members are involved on the BOD or in senior management. Thus as a result, non-family firms from the TEJ are usually government-controlled, management-controlled, or widely held firms.

Reasons for management turnover include managers' dismissal, retirement, resignation, illness, or death. The specific reason, however, for the occurrence of management turnover is often difficult to determine. Although many studies differentiated reasons for changes of executive as either voluntary or involuntary turnover, their main focus 
was on involuntary reasons. Voluntary management turnover due to an executive's death, illness, and retirement are supposed to have little or no impact on firm performance. In addition, it is not customary in Taiwanese culture for firms to publicize death or illness of key personnel. However, a study from Tsai and Chen (2006) examines firms in Taiwan with turnover due to voluntary retirement and report a significant reverse impact on firm performance, as the real reason for turnover is not truly reflected. Furthermore, James and Soref (1981) find firms tactfully offer what is believed to be a suitable excuse, such as "early retirement" or "resignation for a personal/family matter," to explain changes in management instead of expressing what may have been the real reason for the dismissal of managers. Therefore, it is difficult to classify without skepticism the real reasons for executive turnover. Li et al. (2005) point out that no disclosure appears in annual reports or financial statements, most likely due to the fact that sample selection bias would result if researchers classify on their own. Based on the same argument, our study does not make an attempt to differentiate the reasons of turnover, but does take into account the frequency of management turnover.

In addition, the measure of performance most widely used in a company is accounting earnings performance. Sloan (1993) suggests that the use of accounting earnings can avoid volatility in terms of managers' rewards and compensation. Murphy and Zimmerman (1993) also indicate the use of accounting earnings as the measure of a company's operating performance. Therefore, we follow the above suggestion to adopt financial earnings by return on assets (ROA), the most common measure of accounting performance in extant literature. Market performance, however, is also widely used to measure firm performance, as prior literature suggests. Therefore, our second measure of price to market ratio(PB ratio), which is the firm's market value divided by its net book value in the year end, reflects the variation from the capital market responses.

The study also applies the transparency ranking system of information disclosure outlined by the Taiwan Securities and Futures Institute (SFI), which ranks each public firm as A+, A, B, C, or C- : five classes according to the 113 corporate governance related indices. Thus we are able to code from 5 (highest as $\mathrm{A}+$ ) to 1 (lowest as $\mathrm{C}-$ ) which reflects transparency disclosure from highest to lowest levels. . In addition to control variables regarding firm-specific characteristics, other governance variables used in the models include chair and CEO duality, an indicator variable for family firms, and the deviation of ultimate shareholder rights and control equity ownership rights.

Combined with the discussion, the following regression Models (1) to (6) were employed to examine our proposed hypotheses. First, Model (1) and (2) were employed to examine our first set of hypotheses.

Model (1):

ROA $_{\mathrm{i}}=\alpha_{\mathrm{i}}+\beta_{1}$ CEO_TO ${ }_{\mathrm{i}}+\beta_{2} \mathrm{CFO}_{-} \mathrm{TO}_{\mathrm{i}}+\beta_{3} \mathrm{Chair}_{-} \mathrm{TO}_{\mathrm{i}}+\beta_{4} \mathrm{CAO}_{-} \mathrm{TO}_{\mathrm{i}}+\beta_{5}$ Trans $_{\mathrm{i}}+\beta_{6}$ Size $_{\mathrm{i}}+\beta_{7}$ Debt $_{\mathrm{i}}+\beta_{8} \mathrm{OCF}_{\mathrm{i}}+\beta_{9}$ Duality $_{\mathrm{i}}+$

$\beta_{10}$ CFoverHri $+\beta_{11}$ Year $_{\mathrm{i}}+\varepsilon_{\mathrm{i}}$

Model (2):

PBratio $=\alpha_{\mathrm{i}}+\beta_{1}$ CEO_TO ${ }_{\mathrm{i}}+\beta_{2} \mathrm{CFO}_{-} \mathrm{TO}_{\mathrm{i}}+\beta_{3} \mathrm{Chair}_{-} \mathrm{TO}_{\mathrm{i}}+\beta_{4} \mathrm{CAO} \_\mathrm{TO}_{\mathrm{i}}+\beta_{5}$ Trans $_{\mathrm{i}}+\beta_{6}$ Size $_{\mathrm{i}}+\beta_{7}$ Debt $_{\mathrm{i}}+\beta_{8} \mathrm{OCF}_{\mathrm{i}}+\beta_{9}$ Duality $_{\mathrm{i}}+$

$\beta_{10}$ CFoverHri $+\beta_{11}$ ROA $_{i}+\beta_{12}$ Year $_{i}+\varepsilon_{i}$

Also, we apply Model (3) and (4) to test the second set of hypotheses.

Model (3):

$\mathrm{ROA}_{\mathrm{i}}=\alpha_{\mathrm{i}}+\beta_{1}$ CEO_TO ${ }_{\mathrm{i}}+\beta_{2} \mathrm{CFO}_{-} \mathrm{TO}_{\mathrm{i}}+\beta_{3} \mathrm{Chair}_{-} \mathrm{TO}_{\mathrm{i}}+\beta_{4} \mathrm{CAO}_{-} \mathrm{TO}_{\mathrm{i}}+\beta_{5}$ Trans $_{\mathrm{i}}+\beta_{6}$ Size $_{\mathrm{i}}+\beta_{7}$ Debt $_{\mathrm{i}}+\beta_{8} \mathrm{OCF}_{\mathrm{i}}+\beta_{9}$ Duality $_{\mathrm{i}}+$

$\beta_{10}$ CFoverHri $+\beta_{11}$ Family $_{\mathrm{i}}+\beta_{12}$ Year $_{\mathrm{i}}+\varepsilon_{\mathrm{i}}$

Model (4):

PBratio $_{\mathrm{i}}=\alpha_{\mathrm{i}}+\beta_{1}$ CEO_TO $\mathrm{T}+\beta_{2} \mathrm{CFO}_{-} \mathrm{TO}_{\mathrm{i}}+\beta_{3}$ Chair_TO $_{\mathrm{i}}+\beta_{4} \mathrm{CAO}_{-} \mathrm{TO}_{\mathrm{i}}+\beta_{5}$ Trans $_{\mathrm{i}}+\beta_{6}$ Size $_{\mathrm{i}}+\beta_{7}$ Debt $_{\mathrm{i}}+\beta_{8} \mathrm{OCF}_{\mathrm{i}}+\beta_{9}$ Duality $_{\mathrm{i}}+$

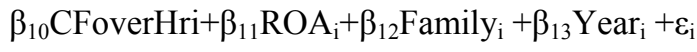

Lastly, we use model (5) and (6) for our third set of hypotheses.

Model (5):

$\mathrm{ROA}_{\mathrm{i}}=\alpha_{\mathrm{i}}+\beta_{1} \mathrm{CEO} \_\mathrm{TO}{ }_{\mathrm{i}}+\beta_{2} \mathrm{CFO} \_\mathrm{TO} \mathrm{i}_{\mathrm{i}}+\beta_{3} \mathrm{Chair}_{-} \mathrm{TO}_{\mathrm{i}}+\beta_{4} \mathrm{CAO} \_\mathrm{TO}_{\mathrm{i}}+\beta_{5}$ Trans $_{\mathrm{i}}+\beta_{6} \mathrm{size}_{\mathrm{i}}+\beta_{7}$ Debt $_{\mathrm{i}}+\beta_{8} \mathrm{OCF}_{\mathrm{i}}+\beta_{9}$ Duality $_{\mathrm{i}}+$

$\beta_{10}$ CFoverHri $+\beta_{11}$ Family $_{i}+\beta_{12}$ Chair_tenure $+\beta_{13}$ CEO_tenure $+\beta_{14}$ Year $_{i}+\varepsilon_{i}$

Model (6):

PBratio $_{\mathrm{i}}=\alpha_{\mathrm{i}}+\beta_{1} \mathrm{CEO} \_\mathrm{TO} \mathrm{i}_{\mathrm{i}}+\beta_{2} \mathrm{CFO} \_\mathrm{TO}_{\mathrm{i}}+\beta_{3} \mathrm{Chair}_{-} \mathrm{TO}_{\mathrm{i}}+\beta_{4} \mathrm{CAO} \_\mathrm{TO}_{\mathrm{i}}+\beta_{5}$ Trans $_{\mathrm{i}}+\beta_{6}$ Size $_{\mathrm{i}}+\beta_{7}$ Debt $_{\mathrm{i}}+\beta_{8} \mathrm{OCF}_{\mathrm{i}}+\beta_{9}$ Duality $_{\mathrm{i}}+$ 
$\beta_{10}$ CFoverHri $+\beta_{11}$ ROA $_{\mathrm{i}}+\beta_{12}$ Family $_{\mathrm{i}}+\beta_{13}$ Chair_tenure $_{\mathrm{i}}+\beta_{14}$ CEO_tenure ${ }_{\mathrm{i}}+\beta_{15}$ Year $_{\mathrm{i}}+\varepsilon_{\mathrm{i}}$

Where:

$\mathrm{ROA}_{\mathrm{i}}$ : the return on assets of firm $\mathrm{i}$.

PBratio $_{\mathrm{i}}$ : the price to market ratio of firm $\mathrm{i}$ at year $\mathrm{t}$. presented by the market value divide by net assets of firm $\mathrm{i}$ at year end $t$.

CEO_TO ${ }_{i}$ : the frequency of CEO turnover of firm $i$ at year $t$;

CFO_TO

Chair_TO $\mathrm{TO}_{\mathrm{i}}$ : the frequency of BOD Chair turnover of firm $\mathrm{i}$ at year $\mathrm{t}$;

$\mathrm{CAO}_{-} \mathrm{TO}_{\mathrm{i}}$ : the $\mathrm{CAO}$ turnover of firm $\mathrm{i}$; presented as an indicator variable of 1 when firm $\mathrm{i}$ has changed their $\mathrm{CAO}$ at year t; otherwise zero.

Size $_{\mathrm{i}}$ : the firm size of firm i; presented by natural log of total assets.

Debt: the debt ratio of firm i; presented by total liability divide by total assets of firm $\mathrm{i}$.

$\mathrm{OCF}_{\mathrm{i}}$ : the cash flow of firm $\mathrm{i}$; presented by total cash flow from operation divide by total assets of firm $\mathrm{i}$.

Duality: the same person serves as the duality position of CEO and BOD chairman in the firm; coded as one if duality exists for firm i, and zero otherwise.

$\mathrm{CFoverHr}_{\mathrm{i}}$ : the deviation of ultimate shareholder rights and control equity ownership rights of firm i; presented by shareholder cash flow rights divide by equity ownership rights.

Family $y_{\mathrm{i}}$ : the firm's ownership is majority controlled by family business; coded as 1 if firm i is a family business ; zero otherwise.

Trans $\mathrm{i}_{\mathrm{i}}$ : the ranking on information transparency of firm's i. (with rank five levels, the higher score is the most transparent).

Chair_tenure $\mathrm{i}$ : the BOD chairman tenure of firm i; presented by the number of years.

CEO_tenure: : the CEO tenure of firm i; presented by the number of years.

\section{Empirical Results}

This study examines the relationship of executive turnover and firm performance during the period of 2006 to 2009 in a Taiwanese sample of 2,233 firm-year observations. The sample distribution of industries is presented in Table 1 and the descriptive statistics are shown in Table 2. Our sample firms are greatly concentrated in the electronics industry (overall $60.4 \%$ ), which is a reflection of the current Taiwan economy. Family-owned businesses consist of $68 \%$ of the sample; and $31 \%$ of sample firms are found to have Chair/CEO duality. The average tenures for Chairs and CEOs are 20.2 years and 15.4 years, respectively.

Table 3 breaks down and summarizes the frequency of high-level executive turnover for sample firms, based on their changes of Chair, CEO, and CFO in panel (A) and CAO in panel (B), on a yearly basis. The results indicate that Chair, CEO, and CFO turnover in the same firm could be as high as three times per year, particularly for 2008 during the global financial crisis. Statistics also show that firms with Chair, CEO, CFO, and CAO turnover are on average $8 \%, 13 \%, 16 \%$, and $14 \%$ of the entire sample, respectively. It is noted that change of CFO was more frequent in 2006: $18 \%$ compared to an average turnover of $16 \%$. The same pattern occurred, as well, in CAO turnover during 2006. The timing of this increase followed the CAO certification requirement in Taiwan that had been put into effect in 2005, when the legal liability of the CAO position increased and CFOs generally assumed "controller/accounting responsibility." Many resignations, it turned out, stemmed from a reluctance of CFOs to bear greater legal liabilities. Other firms separated the accounting function from finance, announced a lower level manger as the CAO, and demanded this new manager certify financial statements. This was evidenced as $14 \%$ of firms changed their accountant-in-charge, driving an increase in the firms' turnover rate to $16 \%$ in 2006 . Chair and CEO turnover were also higher than average during 2007-2008, reflecting the number of firms that were impacted by the onset of the global financial crisis, and who may have changed their high-level executives in an attempt to enhance firm performance.

Table 4 presents the Pearson correlation among main variables. Variance inflation factors (VIF) are examined and fall between 1.0 and 1.6 (not tabulated), implying no significant multicollinearity and posing no concern. Table 5 demonstrates the regression results for testing models. Panel (A) demonstrates the examinations of Hypothesis 1a 
and $1 \mathrm{~b}$ from results in Model (1) and (2), while Panel (B) demonstrates the examinations of Hypothesis 2a and 2b from results in Model (3) and (4). Panel (C) demonstrates the examinations of Hypothesis $3 \mathrm{a}$ and $3 \mathrm{~b}$ from results in Model (5) and (6). From Table 5 we learn that firm accounting performance (proxy by ROA) and CEO, CFO, Chair, and CAO turnovers are negatively associated and the former three variables are all significant at the $1 \%$ level (p-value $<0.01$ ), while the last variable is significant at the $5 \%$ level ( $\mathrm{p}<0.05$ ) regardless of Model (1), (3), and (5). Thus, the hypotheses are accepted, and our evidence consistently supports the findings that firms with executive changes have negatively impacted their accounting performance. The implication is that firms with high-level executive changes may not only cause organizational change but also immediately drag down their firm performance. Table 5 also presents test results of the relation between market performance (proxy by PB ratio in Model (2), (4), (6)) and various types of executive turnovers. The positive coefficients of various executive turnovers, with an exception of CEO, on firms' market performance is not statistical significant, thus an association is not found. However, the existence of a significant and positive relation between PB ratio and CEO turnover (coefficient $=2.248$ with $\mathrm{p}<0.05$, coefficient $=2.235$ with $\mathrm{p}<0.05$, and coefficient $=1.658$ with $\mathrm{p}<0.10$ in Model (2), (4), and (6), respectively) implies that the market views the CEO critical to the firm and responds directly changes in this position.

Furthermore, from the results of Model (3) in Table 5, family-owned businesses are negatively related to their ROAs (coefficient $=-2.111, \mathrm{p}<0.01$ ), which implies that family firms generally underperformed compared to non-family firms, in terms of accounting performance. Thus, hypothesis $2 \mathrm{a}$ is accepted and we learn that there is a significant and negative association between family businesses and their accounting performance. However, the result from Model (4) shows that firms' PB ratios are negatively associated with family firms, but only at a marginally significant level (coefficient $=-0.089, \mathrm{p}<0.1$ ). Therefore, hypothesis $2 \mathrm{~b}$ is also accepted and a negative association is confirmed between family businesses and their market performance. The above results support the finding that family businesses underperform their non-family firm counterparts in accounting performance, and thus attract a more negative market response than received by non-family firms.

Additionally, the results in Panel (C) of Table 5 do not demonstrate any relationship or statistical significance between either a firms' Chair or CEO tenure and the impact on their ROAs. This indicates that a firm with more experienced CEO (and Chair) who has longer tenure in the same position does not necessarily contribute to its ROA performance. Hence we reject hypothesis $3 \mathrm{a}$ and learn that the length of tenure for a firm's executives is not related to its accounting performance. However, the results of Model (6) present that Chair tenure and PB ratio is negatively associated (coefficient $=-0.009, \mathrm{p}<0.01$ ), and the reverse association between CEO tenure and PB ratio is marginal significant (coefficient $=-0.004, p<0.1$ ). Therefore we accept hypothesis $3 b$ that the longer tenure of firm executives may result poorly on its market performance. In other words, the market responds negatively by PB ratio to firms with longer executive tenure.

Other results worth noting include positive associations on accounting performance for firms that are larger, have greater cash flow, and have lower debt ratio. However, firms that are smaller, with higher debt ratio and greater cash flow would induce greater PB ratios on the firm's market performance.

Lastly, there is a positive relation between firms' corporate governance variables, i.e. CFoverHr and transparency, and their ROAs whereas the incident of $\mathrm{CEO} /$ Chair duality and ROA is negatively associated. That indicates that positive accounting performance of the firm may be caused by its tighter corporate governance. However, we learn that governance variable CFoverHr and $\mathrm{PB}$ ratio is negatively associated, and imply the market does not positively value firms with better corporate governance mechanisms.

\section{Conclusion}

Our research purports to examine the relation of high-level executive turnover, family-owned businesses, and firm performance of Taiwanese firms during the period of 2006 to 2009. We include the changes of CEO, CFO, CAO and Chair of BOD as executive turnovers into the study, and separate firm performance as accounting performance (ROA) and market performance (PB ratio). The empirical results provide evidence for our findings that (1) the firm's accounting performance is negatively impacted by its executive turnover, regardless of various levels of executive change. But results do not support the market performance associated with the firm's executive turnovers; the only exception is a positive relation during CEO turnover. (2) Family businesses are underperformed in accounting performance when compared to non-family businesses. Also, the market responds marginally weaker to the performance of family-owned businesses in comparison with their counterpart of non-family firms. (3) The firm with longer tenure of CEO and BOD Chair does not benefit by this tenure, nor does it contribute to an improvement in 
ROA performance. The longer tenures of CEO and Chair, however, associate with the firm's market performance reversely, which implies that the market does not value their long stays in the same post.

Lastly, there are several limitations to this study. Our empirical analysis restricts the sample to years between 2006 and 2009 and excludes the banking and financial industry. These years covered a unique period of global financial crisis and the regulatory change for public firms' CFO and CAO certifications in Taiwan. Therefore, caution must be taken when referring to study results for future reference and application. We also suggest employing additional control variables in a longitudinal study that may include research on the characteristics and personal traits of executives.

\section{References}

Ali, A., Chen, T. \& Radhakrishnan, S. (2007). Corporate disclosures by family firms. Journal of Accounting and Economics 44, 238-286. http://dx.doi.org/10.1016/j.jacceco.2007.01.006

Anderson, R.C., \& Reeb, D.M. (2003). Founding-family ownership and firm performance: evidence from the S\&P500. Journal of Finance 58, 1301-1328. http://dx.doi.org/10.1111/1540-6261.00567

Beatty, R. P., \& Zajac. E. J. (1987). CEO change and firm performance in large corporations: Succession effects and manager effects. Strategic Management Journal 8(4), 305-317. http://dx.doi.org/10.1002/smj.4250080402

Boyd, B. K. (1994). Board control and CEO compensation. Strategic Management Journal 15(5), 335-344. http://dx.doi.org/10.1002/smj.4250150502

Bendeck, Y. M. \& Waller, E. R. (1999). The wealth effects of Non-Senior management departures from investment Banks. Journal of Business Research 46(1), 95-105. http://dx.doi.org/10.1016/S0148-2963(99)00060-0

Chen, Y. (2002). The information content of CEO turnover to corporate operating decisions and performance. Master thesis of Finance, National Cheng-Chi University.

Claessens, S., Djankov, S. \& Lang, L. (2000). Separation of ownership from control of East Asian firms. Journal of Financial Economics 58, 81-112. http://dx.doi.org/10.1016/S0304-405X(00)00067-2

Claessens, S., Djankov, S., Fan J., \& Lang, L. (2002). Disentangling the incentives and entrenchment effects of large shareholdings. Journal of Finance 57, 2741-2771. http://dx.doi.org/10.1111/1540-6261.00511

Dahya, J., Lonie, A.A. \& Power, D.M. (1996). The case for separating the roles of chairman and CEO: An analysis of stock market and accounting Data. Corporate Governance: An International Review 4,71-77. http://dx.doi.org/10.1111/j.1467-8683.1996.tb00136.x

Daily, C., \& Dalton, D. (1993). Boards of directors, leadership and structure: control and performance implications. Entrepreneurship Theory and Practice 17, 65-81.

Dalton, D. R., Daily, C. M., Ellestrand, A. E., \& Johnson, J. L. (1998). Meta-analytic reviews of board composition, leadership structure, and financial performance. Strategic Management Journal 19(3), 269-290. http://dx.doi.org/10.1002/(SICI)1097-0266(199803)19:3<269::AID-SMJ950>3.0.CO;2-K

Eitzen, D. S. \& Yetman, N.R. (1972). Managerial change, longevity, and organizational effectiveness. Administrative Science Quarterly 17, 110-116. http://dx.doi.org/10.2307/2392099

Friedman, S. D. \& Singh, H. (1989). CEO succession and stockholder reaction: The influence of organizational context and event content. Academy of Management Journal, 32, 718-744. http://dx.doi.org/10.2307/256566

Gong, J. J. (2011). Examining shareholder value creation over CEO tenure: A new approach to testing effectiveness of executive compensation. Journal of Management Accounting Research 23(1), 1-28. http://dx.doi.org/10.2308/jmar-10105

Gamson, W. \& Scotch, N. (1964). Scapegoating in Baseball. American Journal of Sociology 70(1), 69-72. http://dx.doi.org/10.1086/223739

Grusky, O. (1963). Managerial Succession and Organizational Effectiveness. American Journal of Sociology 69(1), 21-31. http://dx.doi.org/10.1086/223507

Hermalin, B., \& Weisbach, M. (1988). The determinants of board composition. RAND Journal of Economics 19(4), 589-606. http://dx.doi.org/10.2307/2555459 
Hsu, S. (2008). Reasons for CFO turnover and firm performance. Master thesis of Accounting, Tung-Hai University. [Online] Available: http://ndltd.ncl.edu.tw/cgi-bin/gs32/gsweb.cgi?o=dnclcdr\&s=id=\%22096THU00385011\%22.\&searchmode=basic

Hwang, E. (2006). Management turnover and shareholder wealth effect. The Management Review, 25(1), 23-45.

James, R., \& Soref, M. (1981). Profit constraints on managerial autonomy: Managerial theory and the unmaking of the corporation president. American Sociological Review 46, 1-18. http://dx.doi.org/10.2307/2095023

Khanna, T., \& Palepu, K. (2000a). The future of business groups in emerging markets: Long run evidence from Chile. Academy of Management Journal 43(3), 268-285. http://dx.doi.org/10.2307/1556395

Khanna, T., \& Palepu, K. (2000b). Is group affiliation profitable in emerging markets? An analysis of diversified Indian business groups. Journal of Finance 55(2), 867-822. http://dx.doi.org/10.1111/0022-1082.00229

Khanna, T., \& Rivkin, J. W. (2001). Estimating the performance effects of business groups in emerging markets. Strategic Management Journal 22, 45-74. http://dx.doi.org/10.1002/1097-0266(200101)22:1<45::AID-SMJ147>3.0.CO;2-F

La Porta, R., Lopez-de-Silanes, F., \& Shleifer, A. (1999). Corporate ownership around the world. Journal of Finance 54, 471-517. http://dx.doi.org/10.1111/0022-1082.00115

Lansberg, I. (1999). Succeeding generations: Realizing the dream of families in business. Boston, MA: Harvard Business School Press.

Li, C., Yeh, Y., \& Ho, C. (2005). An empirical study on the relationship among performance, corporate governance, and top executive turnover. Sun Yat-Sen Management Review 13(1),75-106.

Lubatkin, M. H., Chung, K. H. Rogers, R. C. \& Owers, J. E. (1989). Stockholder Reactions to CEO Changes in Large Corporations, Academy of Management Journal 32, 47-68. http://dx.doi.org/10.2307/256419

Mahajan, A. \& Lummer, S. (1993). Shareholder Wealth Effects of Management Changes. Journal of Business Finance and Accounting 20, 393-410. http://dx.doi.org/10.1111/j.1468-5957.1993.tb00263.x

Maury, B. (2006). Family ownership and firm performance: Empirical evidence from Western European corporations, Journal of Corporate Finance 12(2), 321-341. http://dx.doi.org/10.1016/j.jcorpfin.2005.02.002

Mcguire, J. S. \& Naroff, J. (1988). Effects of Top Managers' Cabinet Appointments on Shareholders' Wealth. Academy of Management Journal 31, 201-212. http://dx.doi.org/10.2307/256507

Merton, R.C. (1987). A simple model of capital market equilibrium with incomplete information. Journal of Finance 42, 483-510. http://dx.doi.org/10.1111/j.1540-6261.1987.tb04565.x

Miller, D., Breton-Miller, I., Lester, R., \& Cammella, A. (2007). Are family firms really superior performers? Journal of Corporate Finance 13, 829-858. http://dx.doi.org/10.1016/j.jcorpfin.2007.03.004

Mitton, T. (2002). A cross-firm analysis of the impact of corporate governance on the East Asian financial crisis. Journal of Financial Economics 64(2), 215-241. http://dx.doi.org/10.1016/S0304-405X(02)00076-4

Morck, R., Strangeland, D. A., \& Yeung, B. (2000). Inherited wealth, corporate control, and economic growth: The Canadian disease? In R. Morck (Ed.), Concentrated corporate ownership (pp. 319-369). Chicago: University of Chicago Press.

Murphy, K. J. \& Zimmerman, J. (1993). Financial performance surrounding CEO turnover. Journal of Accounting and Economics 16(1-2-3): 273-315.

Saito, T. (2008). Family firms and firm performance: Evidence from Japan. Journal of Accounting and Economics $22,620-646$.

Schulze, W. S., Lubatkin, M. H. \& Dino, R. N. (2002). Altruism, Agency, and the Competitiveness of Family Firms. Managerial and Decision Economics 23, 247-259. http://dx.doi.org/10.1002/mde.1064

Sloan, R. (1993). Accounting earnings and top executive compensation. Journal of accounting and economics 16(1-2-3), 55-100. http://dx.doi.org/10.1016/0165-4101(93)90005-Z

Stearns, L. B. \& Mizruchi, M. S. (1993). Board composition and corporate financing: The impact of financial institution representation on borrowing. Academy of Management Journal 36, 603-618. http://dx.doi.org/10.2307/256594 
Tsai, H., \& Wang, W. (2009). The price effects of CFO turnover: Event study under conditional heteroscedasticity. Journal of Accounting and Finance Development 2(2), 29-40.

Tsai, L., \& Chen, H. (2006). The impact of corporate governance on sensitivity of firm performance on CEO turnover: Evidence of Taiwanese listed firms. Management Research 6(2), 273-305.

Vafeas, N., \& Theodorou, E. (1998). The association between board structure and firm performance in the U. K.. British Accounting Review 30, 383-407. http://dx.doi.org/10.1006/bare.1998.0075

Wang, W. (2008). The impact of managerial level turnover information on the stock returns. Doctoral dissertation of Graduate Institute of Management Science, Tamkang University.

Ward, J.L. (2004). Perpetuating the family business: 50 lessons learned from long-lasting successful families in business. New York, NY: Palgrave Macmillan.

Warner, J., Watts, R. \& Wruck, K. (1988). Stock prices and top management changes. Journal of Financial Economics 20, 461-492. http://dx.doi.org/10.1016/0304-405X(88)90054-2

Weir, C. M., \& Liang, D. (1999). The governance-performance relationship: the effects of Cadbury compliance on UK quoted companies. Working paper, European Accounting Conference. Bordeaux, France.

Yeh, Y., Lee T., \& Su, Y. H. (2008). Family shareholding and corporate value in concentrated ownership structure environments. Taiwan Banking \& Finance Quarterly 9, 1-30.

Table 1. Industry Distribution of Sample Firms

\begin{tabular}{|l|r|r|r|r|r|}
\hline IndustrylYear & $\mathbf{2 0 0 6}$ & $\mathbf{2 0 0 7}$ & $\mathbf{2 0 0 8}$ & $\mathbf{2 0 0 9}$ & Total \\
\hline Automobile & 5 & 5 & 5 & 6 & 21 \\
\hline Chemical & 28 & 27 & 27 & 27 & 109 \\
\hline Electronics & 320 & 332 & 342 & 349 & 1,343 \\
\hline Foods & 13 & 15 & 15 & 15 & 58 \\
\hline Glass/Plastics & 29 & 30 & 29 & 30 & 118 \\
\hline Papers and Pulps & 6 & 6 & 6 & 6 & 24 \\
\hline Real Estate & 27 & 25 & 22 & 25 & 99 \\
\hline Shipping & 16 & 15 & 15 & 15 & 61 \\
\hline Iron and Steel & 22 & 21 & 23 & 24 & 90 \\
\hline Textiles & 37 & 36 & 36 & 36 & 145 \\
\hline Others & 39 & 38 & 38 & 40 & 155 \\
\hline & & & & & \\
\hline Total & 542 & 550 & 558 & 573 & 2,223 \\
\hline
\end{tabular}

Table 2. Descriptive Statistics

\begin{tabular}{|l|c|c|c|c|}
\hline Variable & Min & Max & Mean & Std Dev. \\
\hline ROA & -96.1 & 48.9 & 5.6 & 9.1 \\
\hline PBratio & 0.22 & 15.92 & 1.58 & 1.18 \\
\hline Total Assets & 152439 & 833471970 & 21371501 & 62816343 \\
\hline Size (NT\$ billions) & 1.27 & 90.21 & 35.32 & 15.99 \\
\hline OCF & -0.75 & 0.87 & 0.07 & 0.10 \\
\hline Chair_TO & 0 & 3 & .08 & .29 \\
\hline CEO_TO & 0 & 2 & .13 & .37 \\
\hline CFO_TO & 0 & 3 & .16 & .41 \\
\hline CAO_TO & 0 & 1 & .14 & .35 \\
\hline Duality & 0 & 1 & .31 & .46 \\
\hline CFoverHr & .43 & 100.00 & 79.19 & 26.25 \\
\hline Transparency & 1 & 5 & 3.11 & .77 \\
\hline Chair_Tenure & .00 & 63.92 & 20.16 & 11.69 \\
\hline CEO_Tenure & .00 & 61.92 & 15.38 & 10.88 \\
\hline Family & 0 & 1 & .68 & .46 \\
\hline
\end{tabular}


Table 3. Frequency of Various Executive Turnovers

Panel (A)

\begin{tabular}{|l|c|c|c|c|c|c|}
\hline Turnover & Frequency & $\mathbf{2 0 0 6}$ & $\mathbf{2 0 0 7}$ & $\mathbf{2 0 0 8}$ & $\mathbf{2 0 0 9}$ & Total \\
\hline CEO & 1 & 50 & 67 & 72 & 65 & 254 \\
\cline { 2 - 7 } & 2 & 8 & 18 & 10 & 10 & 46 \\
\cline { 2 - 7 } & Subtotal & 58 & 85 & 82 & 75 & 300 \\
\hline \multirow{4}{*}{ CFO } & 1 & 75 & 72 & 68 & 59 & 274 \\
\cline { 2 - 7 } & 2 & 24 & 16 & 16 & 10 & 66 \\
\cline { 2 - 7 } & 3 & - & 3 & 3 & 3 & 9 \\
\cline { 2 - 7 } & Subtotal & 99 & 91 & 87 & 72 & 349 \\
\cline { 2 - 7 } & 1 & 40 & 42 & 44 & 30 & 156 \\
\cline { 2 - 7 } & 2 & 6 & 2 & 6 & 2 & 6 \\
\cline { 2 - 7 } & Subtotal & 46 & 44 & 56 & 32 & 178 \\
\hline
\end{tabular}

The table summarizes the frequency of turnovers for CEO, CFO, and Chairman on a yearly basis.

Panel (B)

\begin{tabular}{|l|c|c|c|c|c|}
\hline CAO Turnover & $\mathbf{2 0 0 6}$ & $\mathbf{2 0 0 7}$ & $\mathbf{2 0 0 8}$ & $\mathbf{2 0 0 9}$ & Total \\
\hline Firms without CAO turnover & $\begin{array}{c}456 \\
(84.13 \%)\end{array}$ & $\begin{array}{c}473 \\
(86.00 \%)\end{array}$ & $\begin{array}{c}481 \\
(86.20 \%)\end{array}$ & $\begin{array}{c}515 \\
(89.88 \%)\end{array}$ & $\begin{array}{c}1,925 \\
(86.60 \%)\end{array}$ \\
\hline Firms with CAO turnover & $\begin{array}{c}86 \\
(15.87 \%)\end{array}$ & $\begin{array}{c}77 \\
(14.00 \%)\end{array}$ & $\begin{array}{c}77 \\
(13.80 \%)\end{array}$ & $\begin{array}{c}58 \\
(10.12 \%)\end{array}$ & $\begin{array}{c}298 \\
(13.40 \%)\end{array}$ \\
\hline Subtotal & 542 & 550 & 558 & 573 & 2,223 \\
\hline
\end{tabular}

The table summarizes the number of firms with (without) CAO turnover on a yearly basis.

Table 4. Pearson Correlation

\begin{tabular}{|c|c|c|c|c|c|c|c|c|c|c|c|c|c|c|}
\hline & PB & Chair_TO & CEO_TO & CFO_TO & CAO_TO & Size & Debt & $\mathrm{OCF}$ & Duality & $\mathrm{CFoHr}$ & Chair_tenure & CEO_tenure & Family & Transparent \\
\hline ROA & $.331^{* *}$ & $-.097^{* *}$ & $-.106 * *$ & $-.145^{* *}$ & $-.103 * * *$ & $.120 * *$ & $.261^{* *}$ & $.238 * *$ & $-.077^{* *}$ & -.036 & -.039 & $-.040^{*}$ & $-.130 * *$ & $.103^{* *}$ \\
\hline PB & & -.003 & -0.13 & -.018 & $-.405^{*}$ & $-.055^{* *}$ & -.013 & $.130^{* *}$ & $-.040^{*}$ & $-.087 * *$ & $-.168 * *$ & $-.133^{* *}$ & $.089 * *$ & .025 \\
\hline Chair_TO & & 1.000 & $.247^{* * *}$ & $.123 * *$ & $.092 * *$ & .038 & -.021 & -.029 & -.029 & $-.069 * *$ & $-.082^{* *}$ & $.100^{* *}$ & -.015 & .014 \\
\hline CEO_TO & & & 1.000 & $.174 * *$ & $.096 * *$ & -.015 & -.010 & $.052^{*}$ & $-.044^{*}$ & -.033 & $-.075^{* *}$ & $-.211 * *$ & .001 & -.010 \\
\hline CFO_TO & & & & 1.000 & $.484 * *$ & $-.041^{*}$ & $.050^{*}$ & $-.062^{* *}$ & .013 & .014 & $-.052 * *$ & $.070 * *$ & .016 & -.041 \\
\hline CAO_TO & & & & & 1.000 & -.004 & .001 & $-.047^{*}$ & .021 & .018 & .006 & .021 & .012 & .018 \\
\hline Size & & & & & & 1.000 & $.104^{* *}$ & $.042^{*}$ & $-.086^{* *}$ & $-.197^{* *}$ & $.076^{* *}$ & .016 & $-.056^{* * *}$ & $.245^{* *}$ \\
\hline Debt & & & & & & & 1.000 & $-.216^{* *}$ & -.001 & $.077 * *$ & -.006 & -.013 & $.080 * *$ & $-.074 * *$ \\
\hline $\mathrm{OCF}$ & & & & & & & & 1.000 & -.002 & $-.058 * *$ & -.033 & .011 & $-.096^{* *}$ & $0141^{* *}$ \\
\hline Duality & & & & & & & & & 1.000 & $.171^{* *}$ & $.070^{* *}$ & $.347^{* *}$ & -.016 & -.040 \\
\hline $\mathrm{CFoHr}$ & & & & & & & & & & 1.000 & $.224^{* *}$ & $.193^{* *}$ & $0190^{* *}$ & $-.144^{* *}$ \\
\hline Chair_tenure & & & & & & & & & & & 1.000 & $.517^{* *}$ & $.224 * *$ & $-.041 * *$ \\
\hline CEO_tenure & & & & & & & & & & & & 1.000 & $.153^{* *}$ & $-.060 * *$ \\
\hline Family & & & & & & & & & & & & & 1.000 & $-.143^{* *}$ \\
\hline Transparent & & & & & & & & & & & & & & 1.000 \\
\hline
\end{tabular}

$* * *$ indicate significance level of $1 \%, * *$ indicate significance level of $5 \%, *$ indicate significance level of $10 \%$. The table summarizes results of Pearson correlation coefficients for all variables. 
Table 5. Analysis of Multiple Regressions

(Panel A)

\begin{tabular}{|l|cc|cc|}
\hline & \multicolumn{2}{|c|}{ Model 1 } & \multicolumn{2}{c|}{ Model 2 } \\
\cline { 2 - 5 } & \multicolumn{2}{|c|}{ Dependent variable =ROA } & \multicolumn{2}{c|}{ Dependent variable =P/B ratio } \\
\hline Variable & Coefficient & T-stat & Coefficient & T-stat \\
\hline Constant & -10.318 & $-4.266^{* * *}$ & 2.653 & $0.672^{* * *}$ \\
\hline CEO_TO & -1.938 & $-4.007^{* * *}$ & 0.137 & $0.248^{* *}$ \\
\hline CFO_TO & -1.830 & $-3.768^{* * *}$ & 0.039 & 0.410 \\
\hline Chair_TO & -2.250 & $-3.682^{* * *}$ & 0.032 & 0.458 \\
\hline CAO_TO & -1.318 & $-2.322^{* *}$ & 0.033 & $-3.760^{* * *}$ \\
\hline Size & 0.875 & $5.877^{* * *}$ & -0.071 & $2.376^{* *}$ \\
\hline Debt & -0.092 & $-8.011^{* * *}$ & 0.004 & $0.653^{* * *}$ \\
\hline OCF & 23.868 & $13.616^{* * *}$ & 1.530 & $-3.556^{* * *}$ \\
\hline Duality & -0.936 & $-2.491^{* * *}$ & 0.021 & 0.425 \\
\hline CFover & 0.014 & $2.114^{* * *}$ & -0.003 & $17.431^{* * *}$ \\
\hline Trans & 0.744 & $3.131^{* * *}$ & 0.013 & 0.047 \\
\hline ROA & - & - & & \\
\hline & & & 2,223 & \\
\hline Year Fixed Effect & Yes & & 0.2563 & \\
\hline & & & & \\
\hline N & 2,223 & & & \\
\hline Adj-R & 0.2172 & & & \\
\hline
\end{tabular}

$* * *$ indicate significance level of $1 \%, * *$ indicate significance level of $5 \%, *$ indicate significance level of $10 \%$. Table 5 with Panel (A), (B), and (C) summarizes results of regression model (1)-(6) for testing the hypotheses (1a), (1b), (2a), (2b), (3a), and (3b), respectively. In Panel (A), it summarizes results of regression model (1) and (2) for the association of executive change and firm performance. Dependent variables are ROA in model (1) and PB ratio in model (2) to represent accounting and market performance. Firms' changes of executives are measured by the variables CEO_turnover, CFO_turnover, Chair_turnover, and CAO_turnover along with other control variables.

(Panel B)

\begin{tabular}{|c|c|c|c|c|}
\hline & \multicolumn{2}{|c|}{ Model 3} & \multicolumn{2}{|c|}{ Model 4} \\
\hline & \multicolumn{2}{|c|}{ Dependent variable $=$ ROA } & \multicolumn{2}{|c|}{ Dependent variable $=\mathrm{P} / \mathrm{B}$ ratio } \\
\hline Variable & Coefficient & T-stat & Coefficient & T-stat \\
\hline Constant & -8.867 & $-3.670 * * *$ & 2.708 & $8.814 * * *$ \\
\hline CEO TO & -1.931 & $-4.020 * * *$ & 0.137 & $2.235 * *$ \\
\hline $\mathrm{CFO} \mathrm{TO}$ & -1.813 & $-3.760 * * *$ & 0.038 & 0.624 \\
\hline Chair TO & -2.246 & $-3.700 * * *$ & 0.031 & 0.395 \\
\hline CAO_TO & -1.322 & $-2.345^{* *}$ & 0.032 & 0.445 \\
\hline Size & 0.874 & $5.915 * * *$ & -0.071 & $-3.735 * * *$ \\
\hline Debt & -0.090 & $-7.877 * * *$ & 0.004 & $2.401 * *$ \\
\hline $\mathrm{OCF}$ & 22.845 & $13.048 * * *$ & 1.501 & $6.515^{* * *}$ \\
\hline Duality & -1.069 & $-2.858 * * *$ & 0.015 & 0.311 \\
\hline CFover & 0.020 & $2.959 * * *$ & -0.003 & $-3.220 * * *$ \\
\hline Trans & 0.608 & $2.561 * *$ & 0.007 & 0.248 \\
\hline Family & -2.111 & $-5.580 * * *$ & -0.089 & $-1.835^{*}$ \\
\hline $\mathrm{ROA}$ & - & - & 0.046 & $17.103 * * *$ \\
\hline Year Fixed Effect & Yes & & Yes & \\
\hline $\mathrm{N}$ & 2,223 & & 2,223 & \\
\hline Adj-R ${ }^{2}$ & 0.2277 & & 0.2571 & \\
\hline
\end{tabular}

$* * *$ indicate significance level of $1 \%, * *$ indicate significance level of $5 \%, *$ indicate significance level of $10 \%$. The table summarizes results of regression model (3) and (4) for the association of family business and performance. Dependent variables are ROA in model (3) and PB ratio in model (4) to represent accounting and market performance. Whether the firm is classified as a family or non-family business is measured by the indicator variable Family along with other control variables. 
(Panel C)

\begin{tabular}{|c|c|c|c|c|}
\hline \multirow{3}{*}{ Variable } & \multicolumn{2}{|c|}{ Model 5} & \multicolumn{2}{|c|}{ Model 6} \\
\hline & \multicolumn{2}{|c|}{ Dependent variable $=$ ROA } & \multicolumn{2}{|c|}{ Dependent variable $=\mathrm{P} / \mathrm{B}$ ratio } \\
\hline & Coefficient & T-stat & Coefficient & T-stat \\
\hline Constant & -8.665 & $-3.573 * * *$ & 2.742 & $8.955 * * *$ \\
\hline $\mathrm{CEO}_{-} \mathrm{TO}$ & -2.041 & $-4.177 * * *$ & 0.102 & $1.658 *$ \\
\hline $\mathrm{CFO} \mathrm{TO}$ & -1.849 & $-3.829 * * *$ & 0.019 & 0.316 \\
\hline Chair_TO & -2.274 & $-3.743 * * *$ & 0.016 & 0.208 \\
\hline CAO_TO & -1.311 & $-2.325^{* *}$ & 0.039 & 0.554 \\
\hline Size & 0.877 & $5.905 * * *$ & -0.064 & $-3.370 * * *$ \\
\hline Debt & -0.091 & $-7.887 * * *$ & 0.003 & $2.272^{* *}$ \\
\hline $\mathrm{OCF}$ & 22.908 & $13.056 * * *$ & 1.501 & $6.545 * * *$ \\
\hline Duality & -0.904 & $-2.251 * *$ & 0.057 & 1.119 \\
\hline CFover & 0.022 & $3.118 * * *$ & -0.002 & $-2.072 * *$ \\
\hline Trans & 0.602 & $2.535 * *$ & 0.005 & 0.173 \\
\hline Family & -2.004 & $-5.174 * * *$ & -0.030 & -0.609 \\
\hline $\mathrm{ROA}$ & - & - & 0.046 & $17.063^{* * *}$ \\
\hline Chair_Tenure & -0.007 & -0.403 & -0.009 & $-4.102 * * *$ \\
\hline CEO_Tenure & -0.020 & -1.016 & -0.004 & $-1.662 *$ \\
\hline Year Fixed Effect & Yes & & Yes & \\
\hline $\mathrm{N}$ & 2,223 & & 2,223 & \\
\hline Adj-R ${ }^{2}$ & 0.2277 & & 0.2675 & \\
\hline
\end{tabular}

$* * *$ indicate significance level of $1 \%, * *$ indicate significance level of $5 \%, *$ indicate significance level of $10 \%$. The table summarizes results of regression model (5) and (6) for the association of executive tenure and firm performance. Dependent variables are ROA in model (5) and PB ratio in model (6) to represent accounting and market performance. The firm tenure is measured by the variables Chair_Tenure and CEO_Tenure along with other control variables. 